Proc. Estonian Acad. Sci. Geol., 1993, 42, 1, 23-27

UDC 562:551.733.3

Lennart JEPPSSON*

\title{
SILURIAN EVENTS: THE THEORY AND THE CONODONTS
}

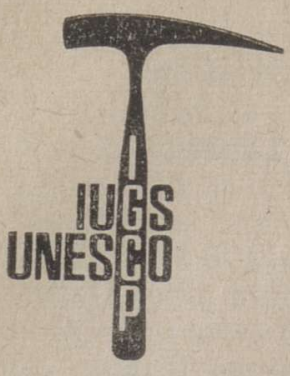

Global Bioevents

\begin{abstract}
A brief review of the seven known Silurian events is given. The globally recognized end-Llandovery-early Wenlock Ireviken Event, which had the strongest effects on the conodont fauna and included ten datum points, is the best known both theoretically and stratigraphically. The second best known is the similar mid-Ludfordian Lau Event. The near extinction of graptoloids is the best known effect of the theoretically different Mulde Event.
\end{abstract}

\section{Introduction}

No Silurian extinction event has to date been included in the standard textbook set, although the Ireviken Event can now defend a place there for three reasons: (1) The high resolution time scale provided by detailed conodont stratigraphy, permitting global identification of Milankovitch cycles. This resolution may be second only to that of the CretaceousTertiary boundary. (2) The detailed correspondence between the record and a theoretical model. (3) The considerable effects. This event falls within a pattern of regular changes between primo and secundo episodes (Jeppsson, 1987, 1990a; also treated by the author, R. Aldridge, and $\mathrm{K}$. Dorning in several works in progress). The unifying character of the events is interpreted to be an abrupt stop in the recycling of nutrients to primary planktic producers, resulting in a collapse of the food chains relying on them, involving most pelagic and many bottom dwelling taxa.

For the true characters of these events to be understood, the responses of evolving lineages during and after the events need to be investigated. The species concept employed is of paramount importance, so that true extinctions are distinguished from mere nomenclatural changes. Walliser (1964) introduced a wide concept for Silurian conodont species, close to the modern one of birds and larger mammals. That is, very different local and temporal populations which nonetheless represent a single lineage are all assigned to the same species. This has largely been followed in studies of Silurian conodonts, which considerably facilitates identification of both the minor events and the general pattern of changes between

* Geologiska Institutionen, Lunds Universitet (Department of Geology, Lund University), Sölvegatan 13, S-223 62 Lund, Sverige. 
episodes and events. In contrast, where à species concept involving morphological splitting has been applied, the distribution of the typical species is often a single local formation; thus, the limits of the gene flow remain unstudied, and "nomenclatural extinctions" dominate.

In addition to the extinctions, changes during an event consist of the replacement of the recurrent conodont association typical for primo episodes by that typical for secundo episodes. It follows that diversity counts alone may give a false picture of the severity of the event and that extinctions were followed by a quick recovery.

Following the instruction to keep the number of references down, I refer to the cited works for further references and the distribution of credit for the reviewed results.

\section{The Ireviken Event}

The Ireviken Event includes ten steps of extinctions and appearances, numbered as Datum points 1 to 8 (Fig.), 3.3., and 6.2. Continuing work may add more such datum points, especially involving Lazarus taxa. The indicators of datum points 3,4 , and 6 have been identified at Leasows, the present type locality for the base of the Wenlock. In the collections of Mabillard and Aldridge (1985), these are found about $0.11,0.22$, and $0.36 \mathrm{~m}$ above the base of the Wenlock. Extrapolation would place Datum 2 within centimetres from the boundary. The boundary between the Monograptus crenulata and the Cyrtograptus centrifugus zones is also commonly taken to indicate the base of the Wenlock, although the first graptolite that indicates the latter zone is found $18.3 \mathrm{~m}$ above the boundary in the type area, but not at the type locality (Bassett et al., 1975). The precision afforded by conodonts is higher than that available at the current type locality with the current definition. Thus, we have either to persevere with a definition of the boundary that imposes unnecessary limitations on correlation, or introduce a third definition of the boundary, e. g. Datum 2 of the Ireviken Event, which is also the strongest one. If this were to be done, then the Ireviken Event would span the boundary, having begun about 31000 years before the end of the Llandovery and having lasted for about 180000 years into the Wenlock.

The event is known from New South Wales in the SE to Alaska in the NW. Most of these areas were in low latitudes. High latitude conodont faunas of this age are virtually unknown. Routine conodont stratigraphic work permits global identification of both the event and most datum points. Conodont studies directed towards pinpointing the exact levels of the datum points have as yet only been performed on Gotland and in Estonia (Jeppsson, 1987; a manuscript by Jeppsson and Männik is in progress).

Forty-five conodont taxa are present to the end of the preceeding Snipklint Primo Episode. The youngest records of 17 others are so close to the end that their extinction most likely was due to the Ireviken Event. Another 10 or 20 taxa which appeared during the event or shortly after must have existed somewhere before the event. Hence, the total number of taxa involved was over 80 . Forty-three of these have provided over 50 well defined range ends (extinctions and Lazarus terminations and reappearances) during the event. In addition, many appeared immediately after the event. Only nine taxa pass through the event interval apparently unaffected.

My model (Jeppsson, 1990a), combined with Milankovitch perturbations, provides a very detailed scenario for the changes during an event (Jeppsson, in press). The Milankovitch cycle with the largest effect, the 
obliquity cycle, caused regular interruptions of the production of new deep water, resulting in periodic stops in upwelling (datum points $1-4$ ). In addition, the repeated stops led to more and more sluggish upwelling, and a lowered threshold for its on-off changes. Thus, during the second phase, weaker Milankovitch perturbations could also inhibit upwelling, leading to closely spaced datum points. The third and fourth phases resulted from a long stable stop in deep water formation, only briefly interrupted by the strongest Milankovitch perturbations during the third phase. The rate of planktic primary production and changes in the diversity/abundance of plankton-dependent taxa closely reflected this. The scenario also relates the varying strength of the datum points, the "Indian summer" after the Second Datum (Fig.), and the similar conditions before it, to Milankovitch control on deep water production.

Panderodus equicostatus dominated the conodont fauna during the third and fourth phases of the event, while P. unicostatus, Decoriconus and

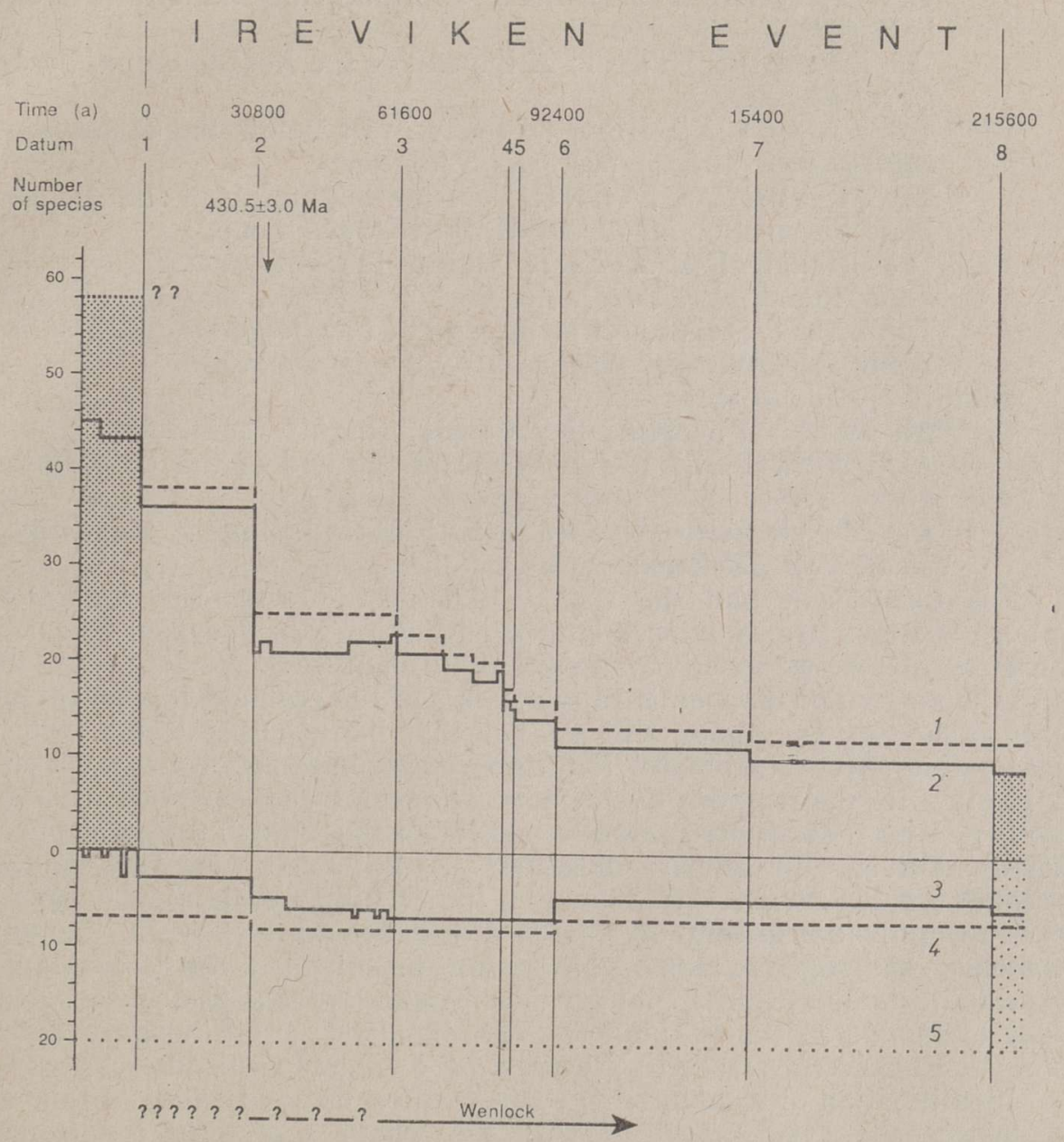

Faunal changes during the Ireviken Event, based on Jeppsson (in press). The uppermost line (1): the fate of the cohort recorded up to the beginning of the event; question marks record taxa known close below the event but not found in a section extending into it. The second line (2): the record; the area between 1 and 2 reflects the temporary absence of Lazarus taxa. Lines 3 and 4 : taxa appearing during the event separated as for 1 and 2. Line 5: the addition of taxa appearing during or after the event. 
Pseudooneotodus spp., Ozarkodina excavata, and Oulodus sp. are found in low frequency. The event affected other groups too, although none have as yet been studied in detail, for example trilobites (at least half of the number of species at Datum 2 on Gotland), brachiopods, corals, pelmatozoans, and probably also graptolites.

\section{Other Silurian Events}

Five similar events, although with far less strong effects on the conodonts, have already been identified in the Silurian (Aldridge et al., in manuscript and Jeppsson et al., in manuscripts). One Silurian event, the Mulde Event, requires a different scenario, being not a P-S but an S-S event (Jeppsson, 1990b). The list of Silurian events now identified includes:

The SANDVIKA P-S EVENT: within the $M$. sedgwickii Zone.

The IREVIKEN P-S EVENT: spanning the Llandovery-Wenlock boundary.

The BOGE P-S EVENT: at the end of the Kockelella patula Zone; C. rigidus Zone.

The VALLEVIKEN P-S EVENT: in or below the Ozarkodina $s$. sagitta Zone and the $M$. testis Subzone.

The MULDE S-S EVENT: from the beginning of the $M$. parvus Zone to parts or all of the $M$. praedeubeli Zone.

The LINDE P-S EVENT: within the Ancoradella ploeckensis Zone; the $M$. chimaera Zone.

The LAU P-S EVENT: at the end of the Polygnathoides siluricus Zone.

Tentatively identified are:

An EARLY PRIDOLI P-S EVENT: highly tentative.

A MID-PRIDOLI P-S EVENT: at the end of the O. eosteinhornensis Zone.

An END-SILURIAN S-(S?) EVENT: starting at the extinction of $M$. transgrediens.

The Lau Event had the second strongest effects. The considerable faunal changes are as widely known as those of the Ireviken Event. The duration of the two events was similar in magnitude (cf Jeppsson, 1987) and the pattern of taxonomic range ends and the residual faunas resemble each other too. The major difference is that the diversity of the recurrent association with stenotopic P-episode taxa had not yet recovered c. $15 \mathrm{Ma}$ after the Ireviken Event. Several of the niches previously occupied by specialist P-taxa were filled by eurytopic taxa which only disappeared briefly. Thereby the number of extinctions became lower. This may also account for the weaker effects of the intervening events. These have not been recognized primarily on conodont evidence but mostly on lithological evidence, although a close look at several of them has revealed the expected conodont faunal changes. The Mulde Event is best known for the near extinction of the graptolites. The tentative end-Silurian event had similar effects and was also preceded by a secundo episode.

Identification of a minor P-S event is often difficult, since in limestone sequences the event, together with the whole preceding P-episode, is typically represented by a very thin $(0-1 \mathrm{~m})$ starved argillaceous unit. More detailed work on sediments, conodonts, and other faunas will probably lead to the discovery of further events.

Acknowledgements. This review would not have been written without the kind invitation from Dimitri Kaljo. Richard J. Aldridge suggested many scientific and linguistic improvements. 


\section{REFERENCES}

Bassett, M. G., Cocks, L. R. M., Holland, C. H., Rickards, R. B. and Warren, P. T. 1975. The Type Wenlock Series. Institute of Geological Sciences Report 75/13, London.

Jeppsson, L. 1987. Lithological and conodont distributional evidence for episodes of anomalous oceanic conditions during the Silurian. - In: R. J. Aldridge (ed.). Palaeobiology of Conodonts. Ellis Horwood Ltd, Chichester, England, 129-145. Jeppsson, L. 1990a. An oceanic model for lithological and faunal changes, tested on the Silurian record. - J. Geol. Soc. London, 147, 663-674.

Jeppsson, L. 1990b. A climatic and oceanic model for events. - In: Global Biological Events, Precambrian-Cambrian Event Stratigraphy 25-27 September 1990, Oxford, 191.

Jeppsson, L. In press. The anatomy of the mid-Early Silurian Ireviken Event. - In: C. Brett (ed.). Paleontological Event Horizons, Ecological and Evolutionary Implications.

Mabillard, J. E. and Aldridge, R. J. 1985. Microfossil distribution across the base of the Wenlock Series in the type area. - Palaeontology, 28, 89-100.

Walliser, O. H. 1964. Conodonten des Silurs. Abhandlungen des Hessischen Landesamtes für Bodenforschung zu Wiesbaden 41.

$$
\text { Presented by D. Kaljo }
$$

Received

September 4, 1992

\section{Lennart JEPPSSON}

\section{SUNDMUSED SILURIS: TEOORIA JA KONODONDID}

On antud ülevaade seitsmest siluri ajastul toimunud bioloogilisest sündmusest. Hästi on uuritud Llandovery lõpul ja Wenlocki algul toimunud globaalse ulatusega nn. Irevikeni sündmus, mis avaldas suurimat mõju konodontide faunale. On eristatud kümme sündmustaset. Samasugune on ka Ludfordi keskel toimunud Lau sündmus. Teoreetiliselt erinev on Mulde sündmus, mis põhjustas paljude graptoliitide väljasuremise.

\section{Леннарт ЕППСОН}

\section{СОБЫТИЯ В СИЛУРЕ: ТЕОРИЯ, КОНОДОНТЫ}

Дан краткий обзор семи биотических событий, произошедших в силуре. Хорошо изученное Иревикское событие конца лландовери - начала венлока следует рассматривать как глобальный кризис, оказавший существенное влияние на фауну конодонтов. Выделено десять уровней этого события. Сходный характер имело Лауское событие в середине ладфорда. Теоретически отличным было Мульдеское событие, обусловившее почти полное вымирание граптолитов. 